The BDJ News section accepts items that include general news, latest research and diary events that interest our readers. Press releases or articles may be edited, and should include a colour photograph if possible. Please direct your correspondence to the News Editor, Arveen Bajaj at the BDJ, The Macmillan Building, 4 Crinan Street, London N19XW or by email to bdj@bda.org

\section{First for UK dentist}

Dr Steven Parker has become the first dentist practicing outside the USA to be made President of the Academy of Laser Dentistry (ALD) for 2005-6. Dr Parker studied dentistry at the University of London and is in private practice in Harrogate, UK. He previously worked in the Department of Oral and Maxillofactial surgery at Harrogate District Hospital for over 15 years, and has been involved in the use of lasers in dentistry since 1990. Before joining the ALD in 1993, he was President of the British Dental Laser Association. He was awarded the Leon Goldman award for Excellence in Clinical Laser Dentistry by the Academy in 1998.

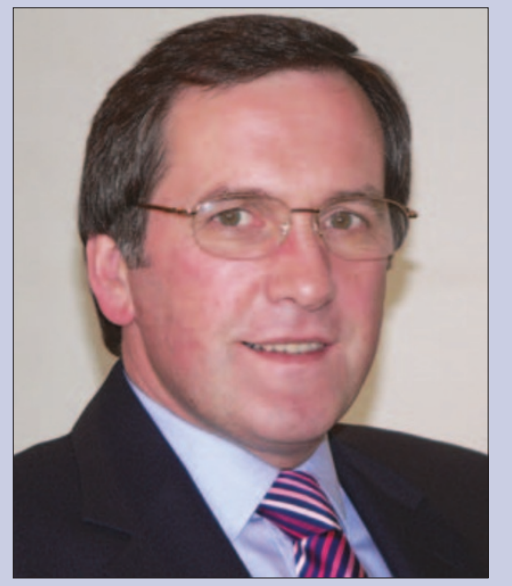

\section{Winners at Junior Papers Day}

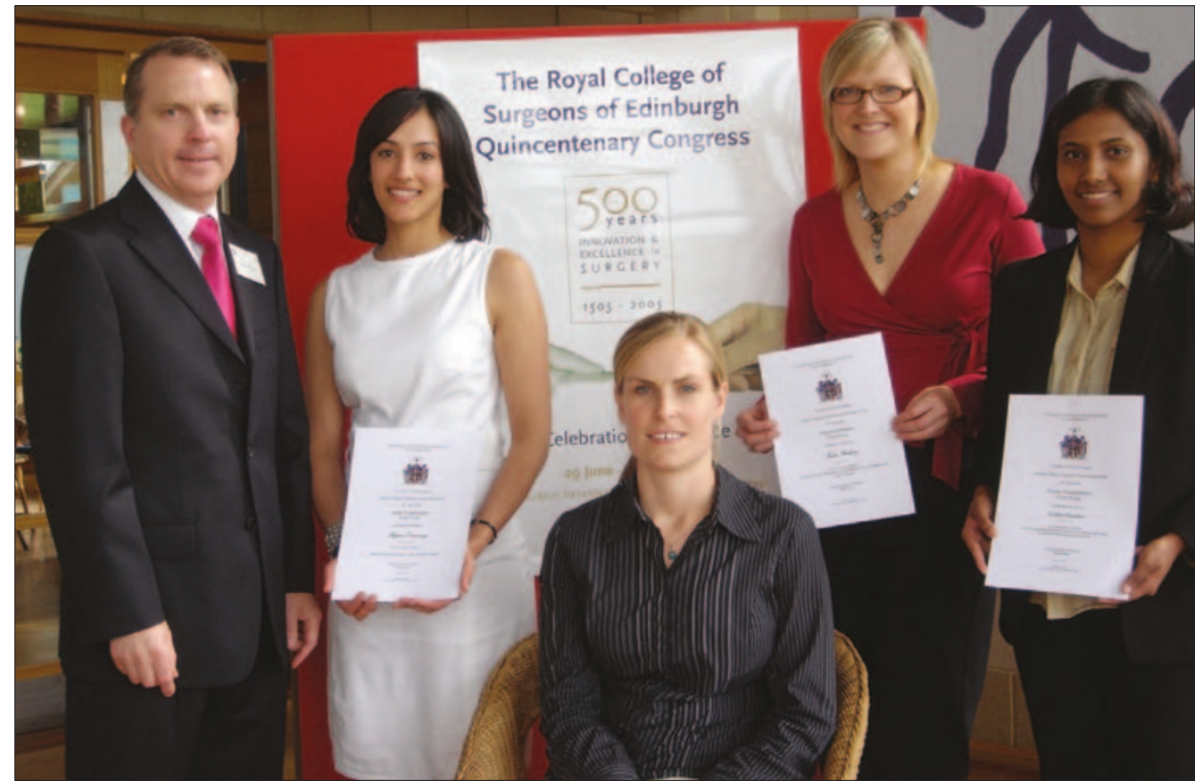

Four winners received awards for the best presentations in the annual Eastern Region Hospitals Junior Papers Day at the British School of Racing in Newmarket last month. As this year marks the Quincentenary of the Royal College of Surgeons of Edinburgh, (RCSEd) the Dean of the Faculty of Dental Surgery, Professor Jim McDonald, gave his approval to inaugurate the college's involvement in the awards. The prize winners were Sarovi Davda, Senior House Officer (SHO) from Luton and Dunstable, for her presentation on Lichen planus and squamous cell carcinoma, Kate Starling, Staff Grade from the Norfolk and Norwich University Hospital, for her presentation on The management of undiagnosed heart murmurs, Anitha Diwakar, SHO from Oldchurch Hospital, for her poster on An audit of compliance of the treatment of children with facial lacerations against national paediatric policies and Megan Downing, SHO from Peterborough Hospital, for her audit presentation on Medical record keeping - the CRABEL score. Pictured from left to right, Rob Chate, the Regional Dental Adviser, RCSEd, Sarovi Davda, Megan Downing, Kate Starling and Anitha Diwakar.

\title{
GDC sets patient standards
}

Six patient care principles are at the heart of the GDC's new guidance for the dental team, Standards for Dental Professionals, which came into effect this month. The GDC expects all dental professionals to apply them to their daily work.

They include putting patients' interests first and acting to protect them, respecting patients' dignity and choices and co-operating with other members of the dental team and other healthcare colleagues in the interests of patients.

The guidance replaces the GDC Maintaining Standards document and explains the standards the Council expects of dental professionals.

As it applies to the whole dental team, the GDC says all dental professionals have a responsibility to work to the new rules.

It has been sent to the GDC's current registrants and will be sent to new registrants when they join, including professionals complementary to dentistry who should be starting to register from 2006.

The guidance can be downloaded from the GDCs website at www.gdc-uk.org.

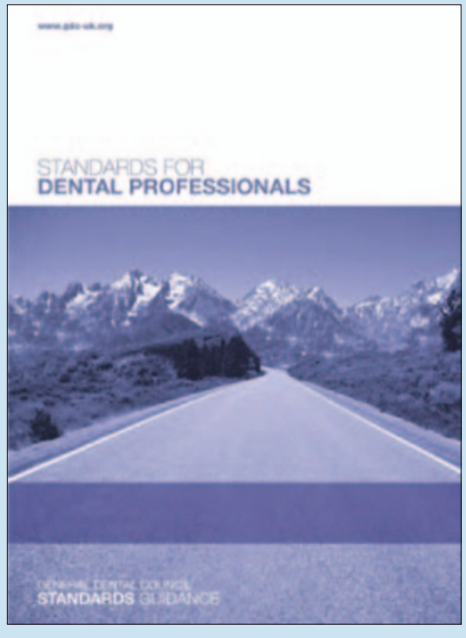


July 2005

Royal Air Force Dental Branch 59th Annual Dinner and Clinical Day

Date: 01.07.05

Venue: Royal Air Force Halton

Contact: Wing Commander Elliot Rhodes

Tel:+ 44 (0) 1296656123

Email:dda8halsdento@defence.mod.uk

Royal Air Force Dental Branch 75th

Anniversary Celebration

Date: 01.07 .05

Venue: Royal Air Force Halton

Contact: Wing Commander Elliot Rhodes

Tel: + 44 (0) 1296656123

Email: dda-8halsdento@defence.mod.uk

\section{August 2005}

FDI World Dental Congress 2005

Date: 24-27.08.05

Venue: Palais de Congrès, Montréal

Email:congress@fdiworldental.org

www.fdiworldental.org

\section{September 2005}

Oral health through public health: Professor Aubrey Sheiham, A Celebration of his work

Date: 5-6.09.05

Venue: University College London

www.ucl.ac.uk/dph

The Irish Endodontic Society 12th Biennial

Congress of the European Society of

Endodontology

Date: 15-17.09.05

Venue: Dublin

Tel: +35316799144

Fax: +35316486197

www.esedublin2005.com

\section{October 2005}

British Dental Trade Association

International Dental Showcase 2005

Date: 6-8.10.05

Venue: NEC Birmingham

Tel: 08702413365

www.dentalshowcase.com

\section{November 2005}

2nd European Congress on the

Reconstruction of the Periodontally

Diseased Patient

Date: 25-27.11.05

Venue: Radisson SAS Scandinavia Hotel,

Copenhagen

Email: kongress@quintessenz.de

www.quintessenz.de/ecrp

Greater New York Dental Meeting

Date: 25-30.11.05

Venue: New York

Email: info@gnydm.com

www.gnydm.com

\section{Numbers of academic dentists decline}

The number of clinical academic dentists has decreased by around $6 \%$ in a single year, and there are $1 \%$ fewer clinical academic doctors, according to new data published this month by the Council of Deans of Dental Schools (CDDS) and the Council of Heads of Medical Schools (CHMS).

The data shows that on 31 July 2004, there were 3,555 full-time education clinical academics in the UK's medical and dental schools compared with 3,617 in 2003. The fall in junior staff is also a concern and there has been a further $14 \%$ decrease in clinical lecturers in the same period.

The Councils surveyed 31 medical and 15 dental schools who were asked to return data on clinical academic grades, specialties, the percentage of full-time clinicians, the nature of the clinical contract, the source of funding, and age, gender and salary details of individual academics.

However, both the CDDS and the CHMS said that the decrease in numbers should be put in context of the current expansion in the sector. Since 2000, four new medical schools have opened, medical student numbers have increased by $40 \%$, numbers of NHS consultants have increased by $25 \%$, and the number of dental students is expected to increase by $25 \%$.

The data also indicated problems seen across the dental specialties, especially in paediatric dentistry, oral surgery, oral pathology and radiology. It also found that more than 50\% of clinical academics were aged over 45 years, suggesting a decline in numbers of clinical academics would continue unless rapid action was taken so that clinical academia is perceived as a more attractive career.

Currently, fewer than $12 \%$ of clinical professors are female and with more women

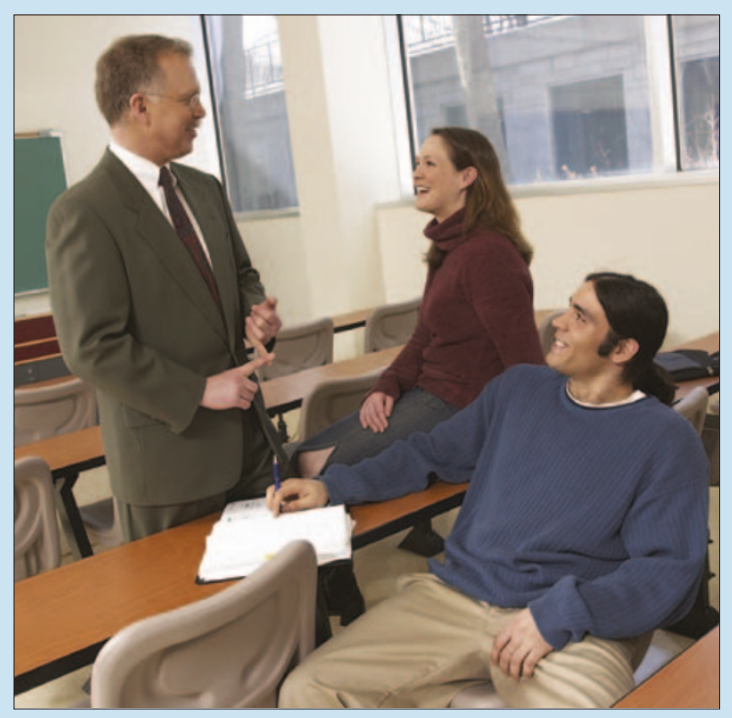
entering medical and dental schools, the groups said that action needed to be taken to increase the attractiveness of an academic career for women.

They added that as the work of clinical academic dentists and doctors enjoyed an unparalleled international reputation, it should be protected while urgent investment was required to reverse the decline. The CDDS represents the 15 Deans and Heads of the University Dental Schools across the UK. A copy of the full survey is available at www.chms.ac.uk.

\section{GDC by-election results announced}

London-based dentist Amolak Singh has been elected to the General Dental Council, following a by-election for England.

He fills the seat previously held by David Barnard, who stepped down as GDC member at the end of last year. Amolak Singh will serve on the GDC until the 9 April 2008, when the five-year term of the current Council comes to an end. Of the 15 dentist members of the Council, 11 are elected from England, the Isle of Man and the Channel Islands, two are elected from Scotland, one is elected from Wales and one from Northern Ireland. In this by-election 24.2\% of the electorate voted (dentists with a registered address in England, Isle of Man or the Channel Islands). 


\section{Controlling tobacco worldwide}

The World Health Organisation's (WHO) World No Tobacco Day launch on 31 May in London focused on the role that health professionals play in tobacco control. The annual event aims to raise awareness of the preventable disease and death caused by smoking, and to promote a tobacco free environment. The UK was approached to host the global launch thanks to its growing international reputation for smoking cessation promotion.

This year's focus was on health professionals as they are in a prime position that allows them to have a prominent role in tobacco control and can reach a high percentage of the population.

In recognition of this, the FDI World Dental Federation and WHO jointly launched a guide for dentists and dental associations on World No Tobacco Day.

The organisations assert that tobaccoinduced oral diseases contribute significantly to the global oral disease burden and that tobacco is a risk factor for oral cancer, adult periodontal diseases, and congenital defects such as cleft lip and palate in children whose mothers smoke during pregnancy.

Dr JT Barnard, Executive Director of the FDI said, "It is my sincere hope that this guide for dentists and oral health professional organisations will be helpful in increasing awareness and in facilitating tangible engagement in tobacco control on the individual patient level as well as in the broader political context."

The advocacy guide is available from the FDI website at www.fdiworldental.org and the WHO website at www.who.int/ oral_health.

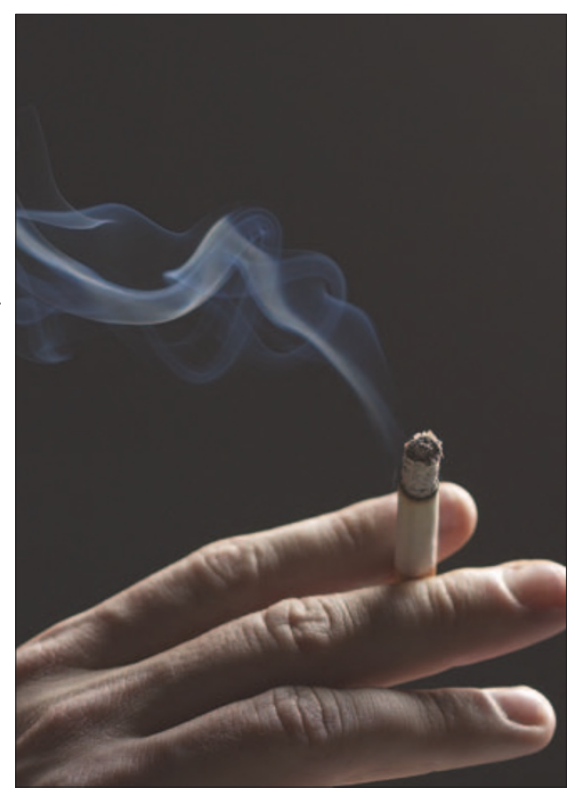

\section{BDA adopts anti-discrimination guidance}

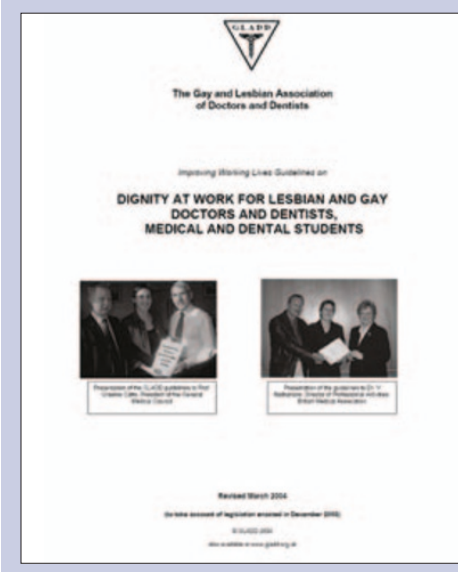

The BDA has formally endorsed and adopted anti-discrimination guidance published by the Gay and Lesbian Association of Doctors and Dentists (GLADD).

The guidance offers advice on best practice and support for employers and employees on how to avoid discrimination against lesbian, gay and bisexual doctors and dentists.

It also offers advice on legal duties and rights, including The Employment Equality (Sexual Orientation) Regulations that came into force in December 2003.

Copies of the guidance are available on the BDA website at www.bda.org or via the BDA legal and advisory team.

\section{Updated directory for medical website}

Medical information website Health On the Net (HON) has recently updated its userfriendly directory of medical terminology. HONselect is based on the 22,568 Medical Subject Headings (MeSH) developed by the US National Library of Medicine. HON has completed a major update of its directory, incorporating new medical terms that have appeared in scientific literature or in emerging areas of research. The 2005 update includes 487 new descriptions, 129 modified existing descriptions and 60 that have been deleted. The websites' French, German, Spanish and Portuguese editions have also been updated. 